\title{
LCA と成形加工
}

河 西 純 一*

\section{1.はじめに}

日本学術会議・リサイクル工学専門委員会・第 2 回リサ イクル工学シンポジゥム〜循環型社会のグランドデザイン の構築を目指して〜が8月 6, 7 日（於日本学術会議）に 開催された。社プラスチック成形加工学会からは，環境・ リサイクル専門委員会（委員長：木村照夫京都工芸䋐維大 学教授) での議論（成形加工に执けるリサイクルのあるべ き姿）をまとめて初日に報告・紹介した。

あるべき姿を模索するには，地球環境負荷を定量化する 「ものさし」が必要であり，LCA（ライフサイクルアセス メント）のような手法で製品・プロセスなどを評価するこ とが重要である.ここで話題にする「LCA」の必要性を 議論する意義が日本学術会議での報告のポイントであり, その報告を引用し，今回の議論の口火を切りたい。

\section{2. 第 1 回リサイクルエ学シンポジウム}

最初に, 第 1 回リサイクル工学シンポジウムで成形加工 学会が主張したことのポイントをまとめてみる.

\section{1 リサイクルすることの効果・意義}

化石資源の節約と，環境保護. そして，ものの大切さを 認識して良識ある人間性の回復へ寄与する.

\section{2 成形加工における課題}

(1)種々のプラスチックや異物が混在

(2)不定形材料を粉研し使用

(3)異形状材料を安定的にシリンダへ送り込むことの困難さ

(4)異種材料，劣化した材料を使用せざるをえない

(5)輸送に伴う環境筫荷の増大

回収・分別し、リサイクル工程へ投入して再生する場合 の技術的・経済的課題と，環境的にリサイクルすることの 是非判断が課題である.

\section{3 日本学術会講への期待}

（1）リサイクルの良否と，最適リサイクル（処分）手法の 指針提供

（2）広範囲な分野でのコミュニケーションによる再生資源 の有効活用の促進（個々の分野では廃萧物であっても， 別分野では貴重な資源であることが考えられるが，学 会活動では分野が特定される傾向がある).

\footnotetext{
* Kasai, Junichi

いすぐ自動車侏 車両研究実験部 材料開発第 2 課兼振動騒音実験課 藤沢市土棚 8（广252-8501） 2002.9.24 受理
}

\section{3. 第 2 回リサイクルエ学シンポジウムでの 成形加工学会の主張}

\section{1 リサイクルすることの効果・意義（再確認）}

化石資源の節約と, 環境保護（埋め立て処分場の不足対 策，埋め立て処分場からの污染流出防止，工場や産業活動 からの廃棄物排出量削減, 市民生活での使用済み製品の有 効活用とごみ発生量の削隇)。そして，ものの大切さを認 識して良識ある人間性の回復へ寄与する.

\section{2 成形加工学会の活動}

環境・リサイクル専阴委員会を設置し，「何をするべき か?」の議論を開始した. 手弁当（専門委員会参加年会費 と, 出席費用自己負担) での少数による委員会活動ではあ るが, いすぶ自動車, 工学院大学, 京都工芸繊維大学, 三 洋電機, スターライト工業, 富士写真フィルム, 三菱電機 （五十音順）からの「産」「学」の委員が集まり, 成形加工 学会として将来のためにやるべきことは何か？について， 情報収集と議論を始めたところである（成形加工学会また は環境・リサイクル尃門委員会として合意された結論まで には到っていません)。

3.3 成形加工学会「環境・リサイクル専門委員会」に おける論点

（1）社会的りサイクル・システム（図 1 全体, 社会性）

（2）リサイクル・コスト（経済性）

（3）リサイクル技術（上流：製品設計, 中間：分別, 下流： 各種リサイクル実用化)

に大別することができる.

以下, 成形加工学会「環境・リサイクル尃門委員会」に おける論点・キーワードを紹介する.

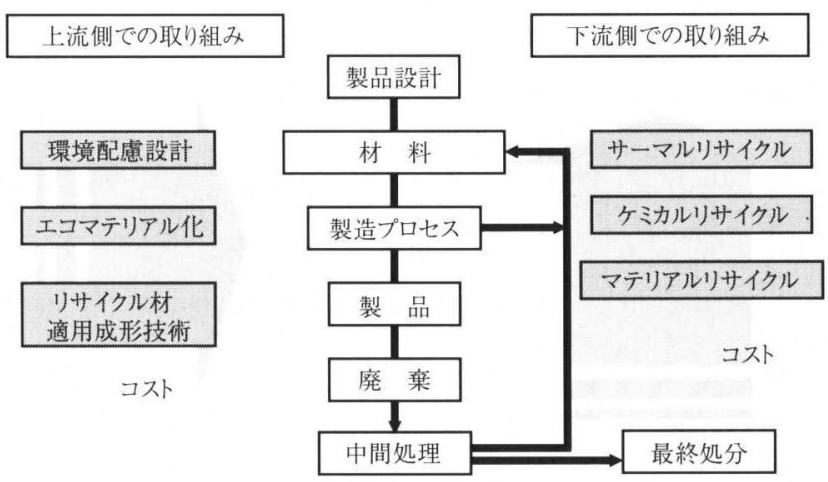

図 1 リサイクル・フローと課題 
（1）社会的リサイクル・システム

資本主義社会であるため，経済性が成立しない場合には 基本的に社会的リサイクル・システムは存続できない. 最 近では，各企業または業界単位での自助努力でリサイク ル・システムを構築”する事例が出始めている。 また, 容 器包装リサイクル法・家電リサイクル法・使用済み自動車 リサイクルイニシアチブなどの法的規制によってシステム が構築・連営され始めている ${ }^{2), 31}$.

どのような社会的システムを構筑するべきかについては， LCA 的に環境負荷を定量化し，最適なシナリオを議論す ることが不可欠である。素材製造や成形加工プロセスにお ける環境負荷デー夕などをきちんと整備したうえで、リサ イクルすることによってどのような功罪（環境筫荷のプラ ス・マイナス）があるのかを数值で評価する必要がある. このような手法の確立と普及，基礎的な環境負荷データの 整備が，学会として取り組むべき課題であるといえる。そ れによって，リサイクルするべきかどうか（別の処理方法 がベターであること考えられる)，どのようなリサイクル がもっとも適しているか，適正な評価と判断が可能となる.

参考に，LCA（ISO 規格における）の概念を図 2 に, 評価対象範囲の概要を図 3 に示す。リサイクルの良否と最 適リサイクル手法を議論するための LCA 調查事例が少な いですが，これは環境負荷データ不足が原因と思われる. リサイクルにおける中間・下流工程での環境負荷データの 拡充も望まれる。

（2）リサイクル・コスト（経済性）

いすぐ自動車では, 使用済みとなったプラスチック (PP：ポリプロピレン) バンパーを回収・分別・粉砕・洗 浄・再生ペレット加工し, 自社製品の部品へリサイクルし ている6. 図 4 に示すようにバンパー1 本当りについて, 廃車と一緒に破砕・埋め立て処分した場合の処理コストを

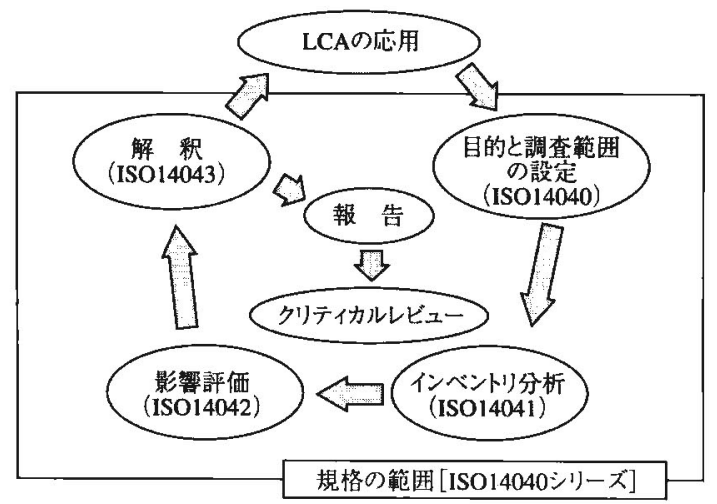

図 2 LCA の概念4,5)
100 とした場合, リサイクル処理コストは, 10 倍以上のコ ストがかかってしまう.リサイクル・コストの中でも，金 具などの分別工程に必要な人件費がもっとも大きく，7割 近くを占め, 次に粉砕・洗浄・再生ペレット加工が 2 割近 く, 輸送コストが 1 割以上となっている（輸送コストだけ で埋めたて処分コストを超えてしまう．しかも，輸送コス トの一部は, 補修部品配送便の州り便を活用しているので ゼロである)。

この事例では，このようにお金をかけても，販売会社に よる回収・分別コスト負担を含め, 種々のコスト削減努力 を行った結果, 再生部品のコストを従来の部品（南洋木材 でできていた）よりも安くできたことが,リサイクルでき た大きな理由である。

リサイクルは廃棄に比べ多額の費用がかかる場合が多く, 経済性の向上はリサイクル浸透のために解決しなければな らない重要な課題である.

（3）リサイクル技術 (上流：製品設計, 中間：分別, 下流： 各種実用化技術)

1) 製品設計

使用する材料の種類を削隇してリサイクルしやすい材料 に統合化し，解体・分別性を著しく向上し，規制物資など の有害と思われる材料を使用せず，といった設計的な配虑 でリサイクルを阻害する因子をつぶしていくことが基本と なる。最近は，従来からの生産性・耐久性や性能を環境負 荷と同時に評価・確認し, 総合的に環境負荷軽減を配慮し たモノ造り（エコデザイン）が重要であると認識されはじ めている. 学会でも更にこの分野を帝引, 活性化すること は, 重要な課題である.

2 ）分別

画期的な技術が発明されれば良いのですが，その可能性

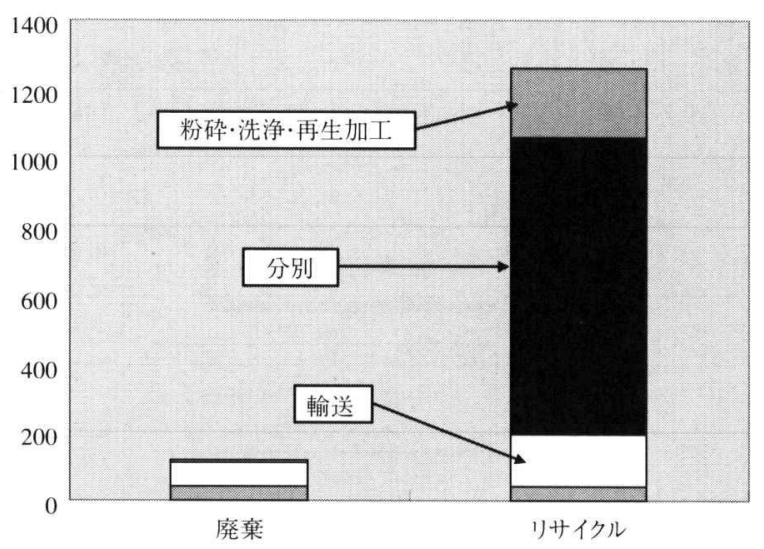

図 4 バンパー処理コスト（実費）比較結果

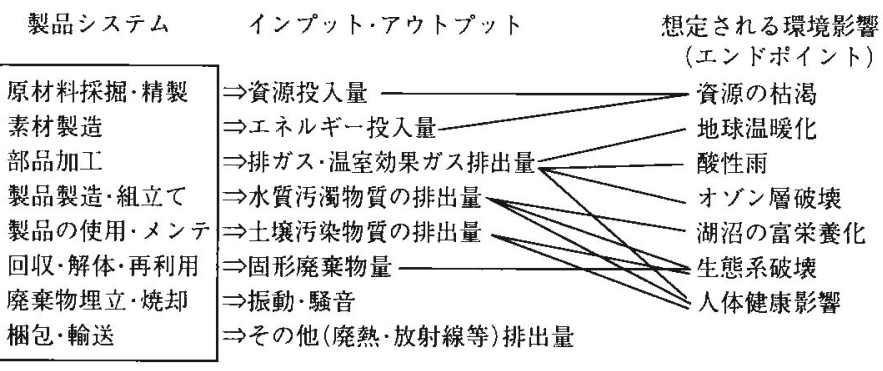

图 3 LCA の範囲・概念 
について, 環境・リサイクル専門委員会のメンバーは悲観 的に考えている. 元から絶つ，つまり「エコデザイン」で どうにかすることが現実的ではないか.

図 5 に分別と各種リサイクル実用化技術のイメージを 示す.

3 ）各種実用化技術

材料技術や成形加工技術で，劣化しにくい材料にしたり， 劣化したリサイクル材をうまく使いこなす技術，相溶化に よって異種プラスチックが混合しても物性低下をおさえる 材料技術など，色々な工夫によってリサイクル実践化を可 能にすることができる分野である.

エコデザインが定着しても，この分野の技術は必要性が 高く, 成果がリサイクルの実践に直結するため, 非常に重 要な課題である.

\section{LCA と成形加工}

成形加工技術分野で取り組むべき課題として，前章で以 下の 3 点を抽出した。

(1)基礎的な環境負荷データの整備（成形加工プロセスや素 材製造における環境負荷デー夕，廃棄・リサイクル中 間・下流工程での環境負荷データ）

(2)環境負荷のプラス・マイナスを数值で評価する手法 （LCA）の確立と普及,

(3)従来からの生産性・耐久性や性能を確保し, 環境負荷軽 減を配慮したモノ造り（エコデザイン）の分野活性化

\section{1 基礎的環境負荷データの整備}

経済産業省が中心になって標準的な（日本平均值）LCA インベントリ・データ・ベースの構築が進められている7). 代表的な汎用プラスチック材料について, 素材 $1 \mathrm{~kg}$ を製 造するのに伴い発生する $\mathrm{CO}_{2}$ 排出量や投入エネルギー量 などのデー夕が(社)日本化学工業会から提供され, 来年度以 降一般に公表される予定になっている.

成形加工分野では，このような共有化情報の開示などは あまり進められていない様子であり, 学会活動を通じて促
進していく必要があると考えられる，当社保有の 2500 卜 ン射出成形機における投入エネルギー量データを表 1 に例 示する.

\subsection{LCA 手法の確立と普及}

成形加工業界のアウトプット製品は，最終製品でない場 合が多い。そのため, 製品のライフサイクル全体を議論す る LCA の手法確立についても, 基礎的な環境負荷データ 構築と同様遅れ気味であろう。

リサイクルの経済性（3.3(2) 項参照）評価と同時に, LCA 調査を実施した事例を図 6〜14に例示する。（詳細に ついては 11 月 6〜7 日に開催される「第 5 回エコバランス 国際会議（つくば）」で報告）ここでは, 概要のみを紹介 する。

LCA 調査に使用したソフトウェアは, PE プロダクトエ ンジニアリング社(独)の GaBi 3 Version 2 で8), いすぶエ ルフ（NKR $66 \mathrm{E} ， 2$ トン積トラック）の PP バンパーを対 象とした. PPバンパーの成形からリサイクル PP の製造, それを使用するタイヤハウスライナー（再生部品）の製造 の前段階である材料調達までを範囲とする。 また, PPバ ンパーによって得られた再生材は夕イヤハウスライナーに 使用（重量比で 10\%）されており, 廃棄時に比較してバー ジン材の使用が少ない。そのため, バージン PP の製造や 輸送も調查範囲に含めた。タイヤハウスライナーの成形は

表 1 PP BUMPER(4.55 kg)の成形に必要なエネルギー

\begin{tabular}{r|c}
\hline & $\mathrm{kWh} / \mathrm{shot}$ \\
\hline 成形機 1 ショットの消費電力 & 5.76 \\
\hline 金型ホットランナー温調 & 0.08 \\
\hline 付帯設備(1)金型温調（ヒーター+チラー） & 1.16 \\
\hline 付帯設備(2)原料供給（ホッパー+ローダー) & 0.95 \\
\hline 合 計 & 7.95 \\
\hline
\end{tabular}

$7.95 \mathrm{kWh} / \mathrm{shot} \rightarrow 1503 \mathrm{kcal} / \mathrm{kg}$ $=6.29 \mathrm{MJ} / \mathrm{kg}$

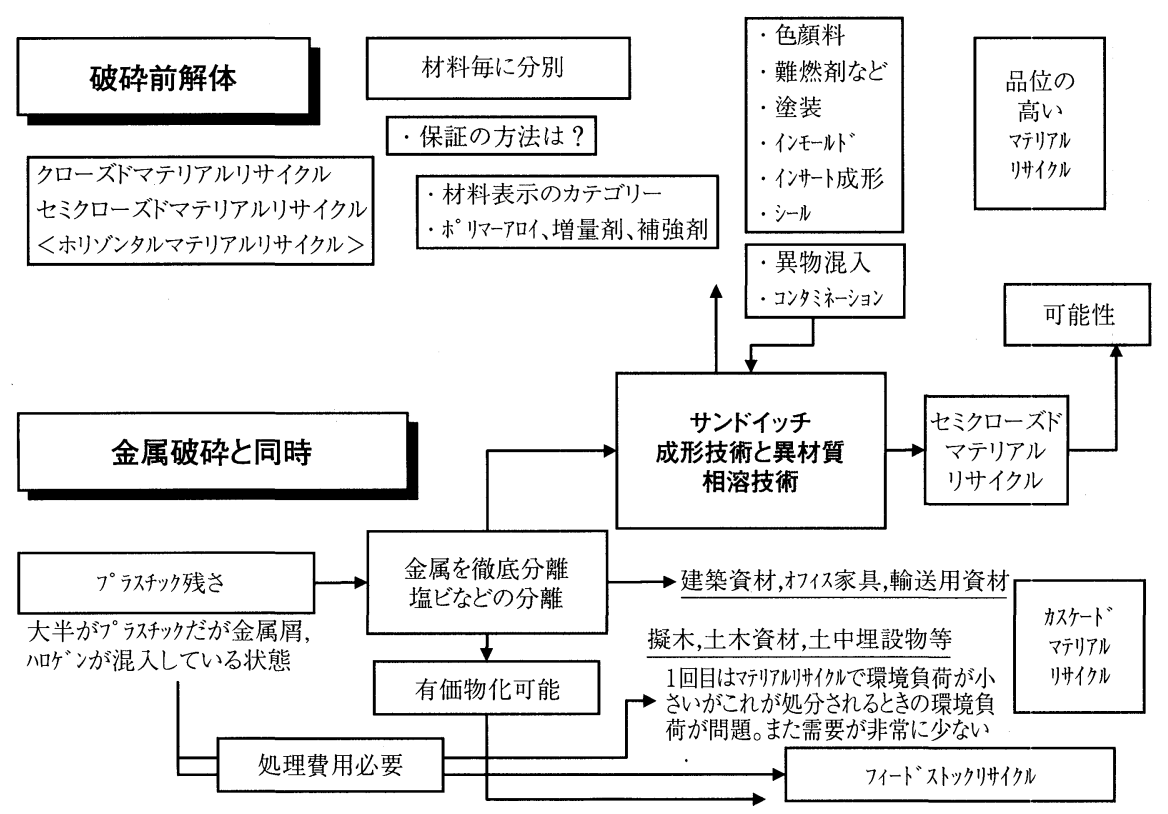

図 5 分別と各種リサイクル実用化技術のイメージ 

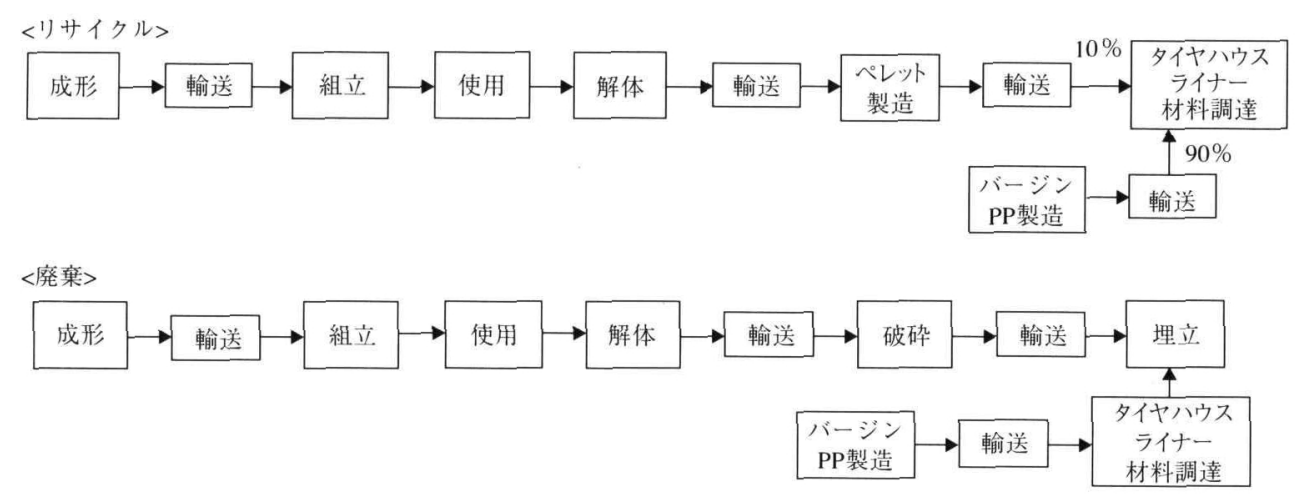

図 6 LCA 調査範囲

材料に関わらず環境負荷が同一であるため，範讲には含め なかった (図 6 参照).

図 7, 図 8 にコインジケータ 95 (環境負荷を総合的に 単一指標化する手法のひとつ）におけるリサイクル時，廃 率時の製品ライフサイクルの環境負荷比を示した。製造・ 使用工程はリサイタル時，廃棄時で同データであるため， それを除いた工程の環境負荷比を図 9，図 10 に示した。

地球温暖化に着目した結果が図11〜14である。図 11，12にリサイクル時，廃棄時における工程別構成比を 示した，使用時や製造時に比べリサイクルや廃棄工程が地 球温暖化に与える影響は小さい。四 $13 ， 14$ にはリサイク ル時, 廃棄時で同データである製造時と使用時の環境負荷 を差し引き，「リサイクル・廃率工程」と「タイヤハウス ライナーの材料製造」の環境負荷比較を示した。

リサイクルするために必要な追加工程に起因する環境負 荷が発生するため，最終処理段階だけに着目すると，単純 に埋め立て処分したほうが環境負荷は小さい。しかし，リ サイクルによって使わずに済むバージン材の環境負荷を軽 減した効果を加味すると、この場合「リサイクルするほう が環境負荷は小さい」と結論付けることができる.

成形加工工程や再生ペレット製造工程など, 自社や協力 企業での環境負荷デー夕を収集し，適用した。このような 事例を公表し共有化することは，成形加工学会関係者での 議諭のきっかけになるものと考えます。

\section{3 エコデザイン分野の活性化}

4.1 項，4.2 項の次の段階には，エコデザインの実践が ある.むしろ，エコデザインへの適用を考えてこれまでに 記述した課題に取り組むべきなのかもしれない。エコデザ イン分野の活性化については，今後の活性化を期待したい.

\section{5.あとがき}

LCAの適用やリサイクルのあるべき姿については，ま だまだ議論の途中段階にあるのが実態である。さらに議覦 を重ね，成形加工学会としていつ・何を実施していくべき か，具体的な課題設定をしていきたい、読者の皆様も，ぜ ひ環境・リサイクル専門委員会へご参加いただきたい．

最後に, 環境・リサイクル専門委員会委員各位には, 話 題・資料を提供していただいた（今回，丸ごと引用した ものもあります）御礼申し上げます。

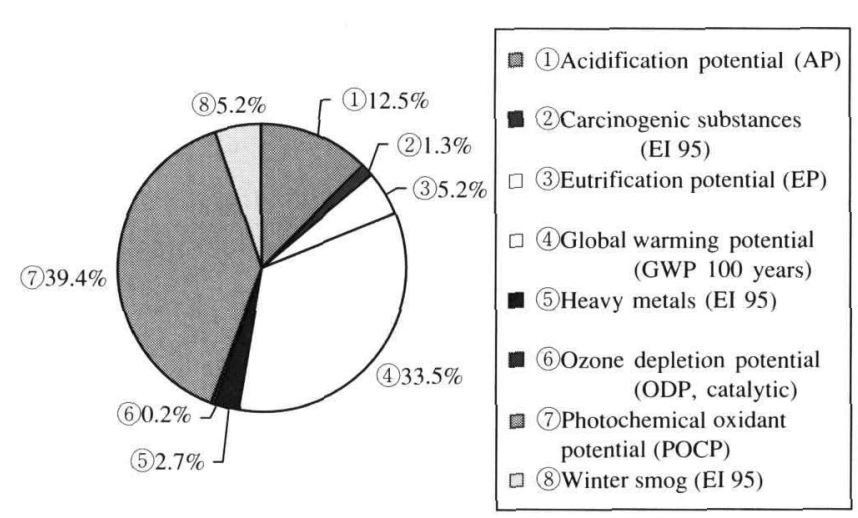

図 7 製品ライフサイクル（リサイクル）の環境負荷構成 比：全体 $0.0514[-]$

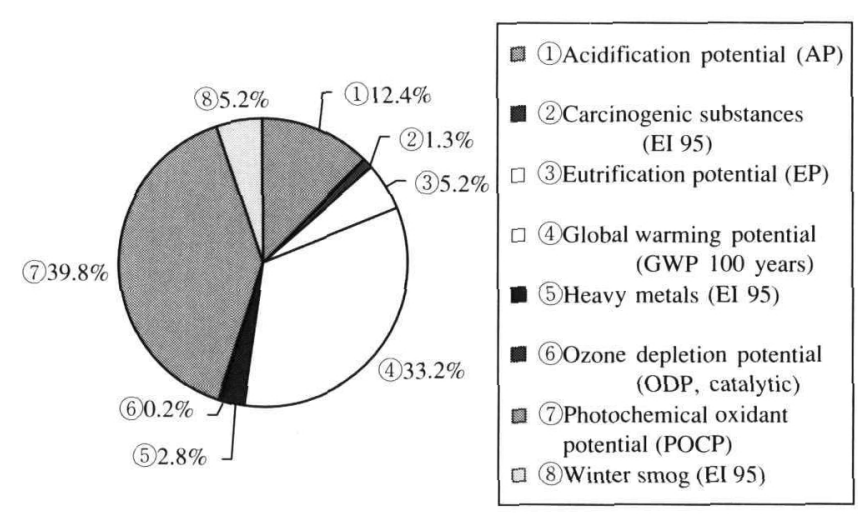

図 8 製品ライフサイクル（廃棄）の環境負荷構成比：全 体 0.0529 [一]

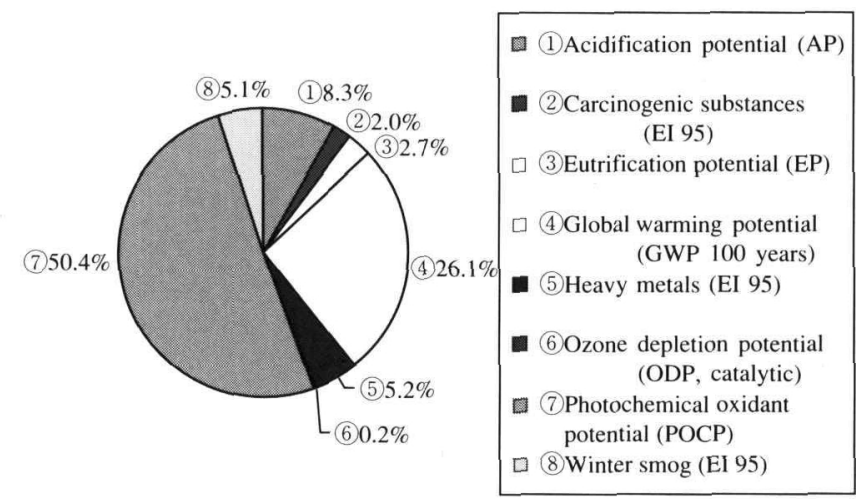

図 9 リサイクル工程の環境負荷構成比：全体 $0.0140[-]$ 


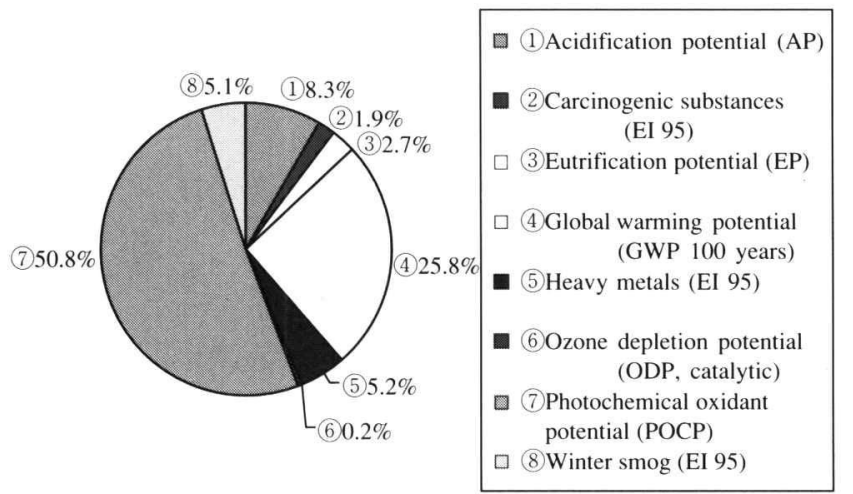

図 10 廃棄工程の環境負荷構成比：全体 0.0514 [- ]

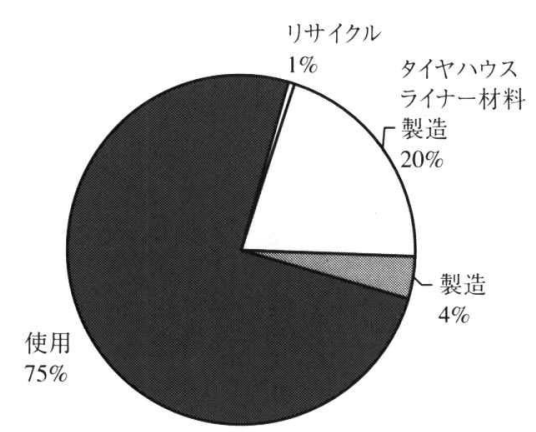

図 11 リサイクル時における工程別環境負荷（GWP 100） 構成比：全体 $226.03 \mathrm{~kg} \mathrm{CO}_{2}$ 当量

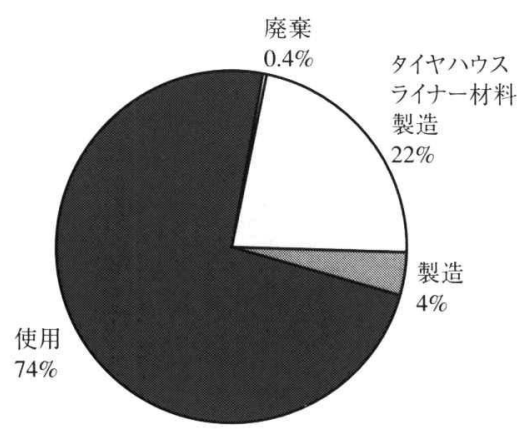

図 12 廃棄時における工程別環境負荷（GWP 100）構成 比：全体 $230.27 \mathrm{~kg} \mathrm{CO}$ 当量

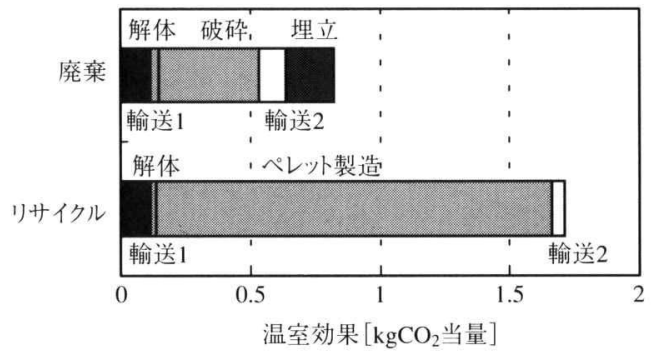

図 13 環境負荷（GWP 100）におけるリサイクル・廃棄 工程の比較

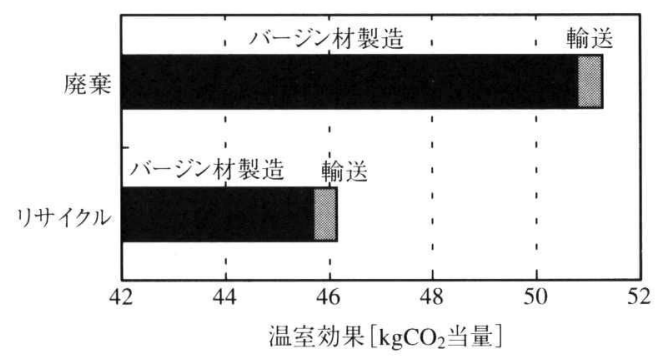

図 14 環境負荷（GWP 100）におけるタイヤハウスライ ナー材料製造工程の比較

\section{考文 献}

1）富永佳博・岡村大輔：レンズ付きフィルム「写ルンで す」ペレタイズレス樹脂再生システムの開発, FUJIFILM RESEARCH \& DEVELOPMENT, No. 47, 12 (2002)

2）河西純一：研究総覧「リサイクル」, 成形加工, 13 (7) (2001)

3 ）佐藤貞雄：研究総覧「リサイクル」, 成形加工, 14 (7) (2002)

4 ）赤井 誠ほか：ISO-LCA ナビゲーションソフトウエ アの開発 (第 2 報), Proceedings of the Forth International Conference on Eco-Balance (Nov. 2000)

5 ) 赤井 誠: ISO-LCA Navigation Software (Version 1. $00 \beta)$, 独立行政法人産業技術総合研究所エネルギー 利用研究部門発行 (Aug. 2001)

6 ）河西純一：自動車の環境負荷定量化とエコデザイン, 自動車技術会 2002 年春季大会前刷集

7 ) http://www.jemai.or.jp/lca/3-1 lca-project.html

8) ホームページ http://www.pe-asia.co.jp/pe_asiac.htm, AND http://www.gabi-software.com 